\title{
Market Power in Distribution and pass-through for Consumers and Producers
}

\author{
April 2018
}

\begin{abstract}
We examine the differential pass-through of import prices into consumer and producer prices. We develop a framework with distribution costs and distribution market power. We then examine pass-through from import prices to consumer and producer prices in the euro area using the US import price as instrument. We find that pass-through rates to producer prices are more sensitive to changes in distribution margins than pass-through to consumer prices. Furthermore, only a portion of import price changes translate into domestic price changes limiting potential consumer benefits from tariff liberalization, with market power in distribution services being one important factor reducing pass-through.
\end{abstract}

Keywords: Pass-through, imports and prices, euro area, market power in distribution services

JEL codes: F14, F42, F36 


\section{Introduction}

Since the mid-1990s, the combination of multilateral and bilateral trade agreements has led to a steady reduction in European barriers to external trade. Since increased openness is widely believed to increase competitiveness, the expectation has been that the resulting drop in prices at the border would lead to both gains for consumers and increased competitive pressure on European industry. In this paper, we examine the extent to which changes in landed import prices have actually reached European consumers, and the extent to which European producers have faced increased pressure linked to pricing.

While we are interested in the consumer and producer impact of changes in landed import prices, the question is closely related to that emphasized in the exchange rate pass-through literature. The focus of this literature has been on pass-through from exchange-rate changes to import prices (Campa and Goldberg, 2005; Campa et al, 2005; Feinberg, 2008; Gaulier et al, 2008), domestic producer prices (Feinberg, 1989, 1996; Feinberg and Kaplan, 1992), and consumer prices (Frankel et al, 2012; Campa and Goldberg, 2006; Hellerstein, 2008; Ihrig et al, 2006; Mishkin, 2008). These studies find ample evidence that pass-through is far from complete, with a substantial heterogeneity in the magnitude of pass-through when looking across both industries and countries (Gaulier et al, 2008; Goldberg and Campa , 2010).

The literature points to a range of explanations for the incomplete consumer price linkage to exchange rate changes. For import prices, the underlying reasons range from local currency pricing (Bachetta and Van Wincoop, 2003), pricing strategies of the exporting firms (Amiti et al , 2014; Campa and Goldberg, 2005, 2006; Burstein and Gopinath , 2014; Berman et al, 2012; Gopinath and Rigobon , 2008; Gopinath, Itskhoki and Rigobon , 2010; Goldberg and Knetter, 1997), trade costs (Fitzgerald, 2008) and frequency of price adjustments (Gopinath and Itskhoki, 2010), to differences in market structure of domestic firms (Auer and Schoenle, 2016) . ${ }^{1}$

For consumer prices, the literature highlights costs added in the distribution and retail sector. For example, both ? and Berger et al (2012) find the distribution wedge (and distribution costs) to be significant (the latter paper finding the distribution wedge to be around $50-70 \%$ ).

\footnotetext{
${ }^{1}$ There is more recent evidence at the firm-level for the above channels, see among others (Amiti et al , 2014; Antoniades, A. and Zaniboni, N. , 2016; Burstein and Gopinath , 2014; Chatterjee et al , 2013; Fitzgerald and Haller , 2014; Hong and Li , 2017; Li, Ma and Xu , 2015; Strasser , 2013).
} 
Goldberg and Campa (2010) also find that distribution margins can dampen border price passthrough into consumption prices. Auer et al (2017) uses retail prices on individual consumer goods and find that the gap between border prices and consumer prices account for a significant part of incomplete exchange rate pass-through at the consumer level in the Swiss case. In addition, some papers find that retailer market structure can have a significant impact on the pass-through rate (see for example Antoniades, A. and Zaniboni, N. (2016) for the case of exchange rate pass-through, Hong and Li (2017) for retail cost pass-through). ${ }^{2}$

Another strand of literature which is also related to this study focuses on the changes in the conditions for domestic producers and resulting effects on margins and producer prices induced by increased trade openness. Here, trade openness is being measured as import penetration. Feinberg (1986) shows that increased market concentration led to reduced pass-through to industrial prices while increased import penetration led to an increase in exchange rate passthrough in Germany (see also Feinberg (1989)). Auer and Fischer (2010) look at the effect of low-wage imports on US producer prices while Chen et al (2010) examine how increased openness affects producer prices and mark-ups in the EU. In accordance with the exchange-rate literature, these studies find that increased trade affects producer prices substantively. ${ }^{3}$

In this paper, we examine the differential impact of changes in landed import prices on consumer and producer prices in the euro area. One of our main contribution relative to the existing literature is that we examine the impact on both consumer and producer prices in a unified framework which involves joint treatment of market power for distribution firms vis-à-vis consumers and market power vis-à-vis suppliers. In order to examine consumer and producer pass-through in a unified framework empirically, we concentrate on final goods. In addition, we also control for transmission of trade policy changes rather than just exchange rate changes. ${ }^{4}$ Furthermore, we examine joint pass-through in a sample based on the euro area countries which

\footnotetext{
${ }^{2}$ Further literature along these lines includes Feenstra et al (1996), Campa and Goldberg (2006); Feinberg $(1986,1989,1991,1996,2008)$ and Yang (1997). In addition, for theoretical models on the importance of the distribution sector, see Corsetti and Dedola (2005); Richardson (2004); Raff and Schmitt (2009, 2008b); Francois and Wooton (2010), as well as the survey by Francois and Hoekman (2010).

${ }^{3}$ In a related paper Auer and Schoenle (2016) examine how domestic firm-level market shares affect passthrough. They find that firms with large and tiny market shares pass through cost shocks while do not react to their (import) competitors. On the other hand, firms with intermediate market shares pass-through some of the own costs and react to competitor prices.

${ }^{4}$ ?Dornbusch (1987) have both stressed that the mechanism behind exchange rate pass-through and real border price pass-through can be analytically analogous. As such, they can work the same way for tariff changes as well. However, the literature on trade policy pass-through is limited. See for example Francois and Wooton (2010); Bloningen and Haynes (2002); Raff and Schmitt (2009, 2008b).
} 
allows us to examine border price transmission in a common currency setting where, in contrast to the United States, we have relatively wide variation across EU Member States linked to differences in regulatory and retail structures.

To formalize the link between internal producer and consumer price transmission, we first analytically decompose factors driving price changes (distribution costs and distribution sector market power) that are expected to contribute to variations in pass-through. Differences between consumer and producer price pass-through are partly determined by market power in the trade and distribution sector. We allow market power to vary in our model ( this is in line with some more recent papers, see for example Cavallo et al (2014)).

Building on the resulting theory, we then examine pass-through to consumer and producer prices from import prices empirically in the euro area member states for the period 1996-2006. Our sample population is characterized by a common trade policy and identical exchange rate changes. Yet it also has relatively segmented trade and distribution sectors. In order to address potential endogeneity of the import prices, we undertake a simultanous equation instrumental variable regression using the US' import prices as our main instrument. We find that passthrough rates are lower as distribution margins increase, both in the case of producer and consumer prices. In addition, we find a larger decrease in pass-through rates from landed import prices to producer prices as distribution margins and distribution costs increase than in the case of consumer prices. When distribution margins are lower than average (one standard deviation lower than the sample mean), consumer price pass-through is around $41 \%$ and producer price pass-through is around $45 \%$ in our main specification. With average distribution margin consumer price pass-through becomes $33 \%$ while producer price pass-through drops to 19\%. We undertake several robustness checks (i.e. including additional control variables, distinguishing differentiated goods, using an alternative measure of market power) and our main results hold, pointing out the importance of distribution margin in restricting the pass-through to both consumer and producer prices.

The paper is organized as follows. In section two, we develop a theoretical framework yielding basic estimating equations for the empirical exercise in section three. In section four we offer concluding comments. 


\section{Theoretical framework}

We start by developing an analytical framework where consumers buy a mix of imported and competing domestic goods. In formal terms, we assume that imports are supplied by a foreign or external sector according to the import supply function in equation (1) below.

(1) $P_{\text {cif }}=F\left(q_{M}\right) \quad F^{\prime}>0$

In equation (1), $P_{\text {cif }}$ is the c.i.f. price before duties, and valued at the foreign exchange rate, while $q_{M}$ is the quantity of imports. We convert $P_{c i f}$ to a landed price for imports $P_{M}$ by applying the exchange rate $e$ and the tariff $T=1+\tau$. This yields equation (2).

(2) $\quad P_{M}=e \cdot T \cdot P_{c i f}=e \cdot T \cdot F\left(q_{M}\right)$

There is also a home or internal industry that competes with imports in supplying the trade and distribution chain that leads to final consumers. ${ }^{5}$ It is also characterized by a standard upward sloping supply schedule.

(3) $P_{H}=S\left(q_{H}\right) \quad S^{\prime}>0$

In equation (3), $q_{H}$ is home supply, and $P_{H}$ is the price paid to home or internal market producers.

Total consumer demand, defined over domestic and foreign supply, is a function of consumer prices $P_{C}$ as in equation (4), where $P_{C}$ represents domestic prices at the final consumer level.
(4) $\quad P_{C}=D\left(q_{M}+q_{H}\right)=D(Q)$
$D^{\prime}<0$

Consumer goods, whether sourced domestically or abroad, reach consumers through a trade and distribution sector. Profits for a representative firm in this sector are defined by equation (5). In equation (5), $\pi_{j}$ is firm profit, $q_{M j}$ and $q_{H j}$ are firm $\mathrm{j}$ sales of imports and domestic goods, and $\varsigma$ the total cost for intermediate trade and distribution services assumed to be

\footnotetext{
${ }^{5}$ We could elaborate the present structure to include numerous sources of supply, with varying degrees of oligopsony power captured through the first derivatives of the corresponding supply curves.
} 
a function of total volume. Profit maximisation involves the standard rule of intermediaries setting marginal revenue equal to marginal cost, and so choosing optimal quantities. Because these firms are providing intermediation services, they optimise with respect to two margins marginal revenue with respect to consumers, and marginal costs with respect to suppliers of consumer goods. This applies to sourcing both at home at quantity $q_{H j}$ and also abroad at quantity $q_{M j}$. The underlying profit maximising equations assuming a constant per-unit cost $\varsigma$ for trade and distribution services are equations (6) and (7). ${ }^{6}$

$$
\begin{aligned}
& \pi_{j}=\left(P_{C}-P_{M}\right) \cdot q_{M j}+\left(P_{C}-P_{H}\right) \cdot q_{H j}-\varsigma\left(q_{M}+q_{H}\right) \\
& \partial \pi_{j} / \partial q_{H j}=q_{j} D^{\prime} \partial Q / \partial q_{H j}+P_{C}-P_{H}-q_{H j} S^{\prime} \partial q_{H} / \partial q_{H j}-\varsigma=0 \\
& \partial \pi_{j} / \partial q_{M j}=q_{j} D^{\prime} \partial Q / \partial q_{M j}+P_{C}-P_{M}-q_{M j} e T F^{\prime} \partial q_{M} / \partial q_{M j}-\varsigma=0
\end{aligned}
$$

To simplify equations (6) and (7) we adopt the following definition for the index $s$ where $\{s \in \mathbb{R} \mid 0 \leqslant s \leqslant 1\}$. The index $s$ measures the degree of market power exercised by the representative firm. When $s=0$ the firm behaves competitively. When $s=1$ the intermediate firm prices as if it were a monopsonist/monopolist. Note that $s$ can be used to represent a Cournot equilibrium where $s=n^{-1}$ and $n$ is the number of firms. In more general terms, it can be thought of as the effective market power exercised by the sector as limited or encouraged through the regulatory and market environment. In other words, $s$ is a measure of the extent to which the regulatory environment supports collusive behaviour. Working now with $s$, we re-write equations (6) and (7) as in equations (8) and (9).

$$
\begin{aligned}
& \left(1+s \varepsilon_{D}^{-1}\right) P_{C}=\left(1+s \varepsilon_{S H}^{-1}\right) P_{H}+\varsigma \\
& \left(1+s \varepsilon_{D}^{-1}\right) P_{C}=\left(1+s \varepsilon_{S M}^{-1}\right) P_{M}+\varsigma
\end{aligned}
$$

\footnotetext{
${ }^{6}$ The framework developed here can be expanded to include imperfect substitutes between imports and domestic goods. In this case, assuming a CES demand structure, equation (4) would then define aggregate demand in terms of the CES composite price, and quantities $q_{H}$ and $q_{M}$ are then a function of relative prices, while the profit functions are then expressed over two consumer prices. The mechanics of double marginalization carry through to imperfect substitutes and CES-type functions forms. See for example Dobson and Waterson (2007) and Francois and Wooton (2010). We can expect pass-through from import prices to domestic prices to be less, the lower the degree of substitution between domestic goods and imported goods. This should apply to both producer and consumer prices. While beyond the scope of the present paper, it may be that differences in pass-through rates across product categories provide an indirect measure of degrees of substitutability, once controlling for other factors identified here.
} 
We define the ratio of consumer price to full marginal cost (goods and intermediate services) $\mu$ and the ratio of marginal cost to supply price (home or imported) $\phi_{z}$ where $z=H, M$ as follows.

(10) $\mu=\left(1+s \varepsilon_{D}^{-1}\right)^{-1}$

(11) $\phi_{z}=\left(1+s \varepsilon_{S z}^{-1}\right) \quad z=H, M$

Making some substitutions and re-arranging equation (9) we arrive at equation (12).

(12) $P_{C}=\mu\left(\phi_{M} P_{M}+\varsigma\right)=\left(1+s \varepsilon_{D}^{-1}\right)^{-1}\left(\left(1+s \varepsilon_{S_{M}}^{-1}\right) P_{M}+\varsigma\right)$

We next differentiate and rearrange equation (12).

$$
\begin{aligned}
& \frac{d P_{C}}{P_{C}}=\frac{\mu \varsigma}{\mu \varsigma+\mu \phi_{M} P_{M}} \frac{d \varsigma}{\varsigma}+\frac{\mu \varsigma}{\mu \varsigma+\mu \phi_{M} P_{M}} \frac{d \mu}{\mu}+\frac{\mu \phi_{M} P_{M}}{\mu \varsigma+\mu \phi_{M} P_{M}} \frac{d P_{M}}{P_{M}} \\
& +\frac{\mu \phi_{M} P_{M}}{\mu \varsigma+\mu \phi_{M} P_{M}} \frac{d \phi_{M}}{\phi_{M}}+\frac{\mu \phi_{M} P_{M}}{\mu \varsigma+\mu \phi_{M} P_{M}} \frac{d \mu}{\mu}
\end{aligned}
$$

This brings us to equation (13) providing a link between import price changes and consumer price changes:

(13) $\hat{P}_{C}=\hat{\mu}+\alpha_{\varsigma} \hat{\varsigma}+\alpha_{M} \hat{P}_{M}+\alpha_{M} \hat{\phi}_{M}$

where $\alpha_{M}=\frac{\phi_{M} P_{M}}{\varsigma+\phi_{M} P_{M}}$ is the import share of marginal cost and where $\alpha_{\varsigma}=1-\alpha_{M}$ is the service cost share of marginal cost.

To derive the pass-through equation for home producer prices, we start with equation (8). Re-arranging, we have:

(14) $P_{H}=\phi_{H}^{-1}\left(\mu^{-1} P_{C}-\varsigma\right)$

We can substitute equation (12) into equation (14). Differentiating, we then arrive to the following equation:

(15) $\hat{P}_{H}=\hat{P}_{M}+\hat{\phi}_{M}-\hat{\phi}_{H}$ 
The interpretation of these equations can be made assuming competitive markets or assuming markets where we have some market power.

With competitive markets the markup terms $\mu$ and $\phi_{z}$ are not relevant, and equation (13) then collapses to the following:

(16) $\hat{P}_{C}=\alpha_{\varsigma} \hat{\varsigma}+\alpha_{M} \hat{P}_{M}$

Thus in competitive markets the consumer pass-through coefficient depends on service cost shares. With similar reasoning, the market power terms will not enter in equation (15) defining producer price pass-through, and hence the producer prices will depend only on import prices.

With market power, what drives changes in consumer and producer prices is not only changes in import prices (i.e. the direct pass-through effect) but also changes in market power $s$, as this will lead to changes in the markup terms $\mu$ and $\phi_{z}$. In addition, changes in market power $s$ can lead to changes in the cost share terms (as can be seen in equation 13 and in the definition of $\alpha_{M}$ and $\alpha_{\varsigma}$ ). The first of these is direct - increased market power leads to higher values for $\mu$ and $\phi_{z}$. The second is indirect as greater market power leads to a shift in the value of $\phi_{M} P_{M}$ as equilibrium conditions will be different resulting in an indirect effect through $\alpha_{M}$ and $\alpha_{\varsigma}$. This points to an interaction between market power and the pass-through term in our estimating equations below.

\section{Empirics}

We turn next to an empirical assessment. We have organized the rest of this section as follows. We first present our estimating framework which links our theory to the empirics. The following subsection discusses the data used for the emprics. Then we present our main results, and robustness checks.

\subsection{Estimating framework}

In what follows, we focus our attention on equations (13) and (15), estimating the rate of pass-through into consumer and producer prices respectively. We follow equation (13) for our 
empirical specification of the consumer price pass-through. According to equation (13) changes in consumer prices are driven by changes in distribution costs, distribution margins, import prices, and interactions. This is reflected in our estimating equation (17) for the consumer price pass-through. For our producer price estimation we follow equation (15) which indicates that distribution margins and import price changes drive producer price changes, which we approximate with our empirical specification set out in (18) where we also allow for interactions.

(18) $\ln \left(P_{H i t k}\right)=b_{0}+b_{1} \ln \left(P_{M i t k}\right)+b_{2} \ln \left(S_{i t}\right)+b_{3}\left[\ln \left(S_{i t}\right) \times \ln \left(P_{M i t k}\right)\right]+\beta_{i k}+\delta_{t}+\epsilon_{i t k}$

Note that equations (17) and (18) define changes in prices (thus we use price indexes), and as such we are mapping differences in the rate of change in landed import prices, relative to the rate of change in both consumer and producer prices. In addition, we also control for market power and service cost margins, where the level of observations vary by country (i), time (t)). The term $S$ is an index of competition per our discussion of $s$ above, proxied with a retail market competition index from the OECD. $C$ is the price of margin services $\varsigma$ (trade and distribution), measured by a price index of distribution services as explained below in more detail. Both equations include also country-sector fixed effects $\left(\beta_{i k}\right)$ and time fixed effects $\left(\delta_{t}\right)$.

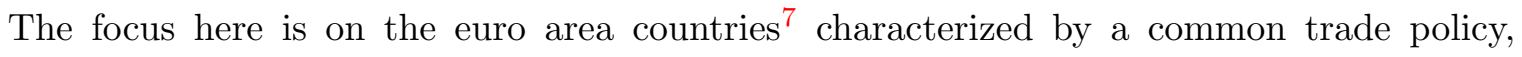
common currency with uniform exchange rate movements and a common market. We do not look at exchange rate pass-through in a bilateral setting, but instead examine how changes in landed import prices (thus price changes from all sources after tariffs and exchange rates are applied) translate into consumer and producer price changes across sectors, euro area countries, and years.

Even when using country-product specific fixed effects, time fixed effects, and estimating equations (17) and (18) using a seemingly unrelated regression estimator (Zellner 1962), hence controlling for (contemporaneous) errors associated with the dependent variables that may be

\footnotetext{
${ }^{7}$ Belgium-Luxembourg, Germany, Ireland, Greece, Spain, France, Italy, Netherlands, Austria, Portugal, Finland, furthermore we also include Denmark given that during the period it had a fixed peg to the euro.
} 
correlated, there could still be an endogeneity problem if producer or consumer prices and import prices are simultaneously determined by common (country-product-specific) time-varying factors for which we do not control for. In other words, there could be some time varying country-sector specific local demand shocks for which we do not control for which could influence both import and domestic prices. Therefore estimating the import price pass-through to consumer and producer prices requires an identification strategy addressing this issue. Thus we undertake an instrumental variable estimation with a three-stage estimation for systems of simultaneous equations. As instruments, we use third country product-level import prices which are unlikely to be correlated with local demand shocks while are positively correlated with changes in world-level prices and hence import prices. More specifically, we use the US's import price at the same level of coicop aggregation as our dependent variable, as these are expected to be exogenous to firm/sector level demand shocks at country-level. As a robustness check, we also use exchange rate as an instrument.

\subsection{Data}

We work with data from a number of different sources, namely EUROSTAT (consumer prices, producer prices), COMTRADE (import prices), WITS (import protection), OECD (retail sector competitiveness), WIOD (retail and wholesale services prices), and the IMF (exchange rates). Organizing the data has involved mapping detailed trade and production data to detailed consumer price series for all individual countries. Our dataset covers the period 1996-2006.

\subsubsection{Prices}

Import prices in our data were constructed from trade data obtained from the World BankUNCTAD WITS database. Trade data include quantity and the value of trade for detailed product categories at HS6-level. ${ }^{8}$ From the quantity and value data we calculate unit values which we use as a measure of import prices. This is a common practice in the literature (e.g. Schott (2004), Hummels and Lugovskyy (2009), Bekkers, et al. (2012) among others). A potential caveat is that there could be some measurement problems in the data (possibly related to quantity measurement issues). This could result in outliers (both potentially tiny

\footnotetext{
${ }^{8}$ About $8 \%$ of all trade data had missing quantities. Since for the analysis we use unit values, missing observations had to be eliminated, together with observations where the quantities were not recorded in weight.
} 
and very large values) thus we winsorize the upper and lower $10 \%$ to reduce this potential problem. Figure 1 provides a scatter plot between aggregate import prices and our proxy for import prices baesd on unit values, together with the correlation between the two. Based on that we believe that our measure provides a reasonable approximation for import prices.

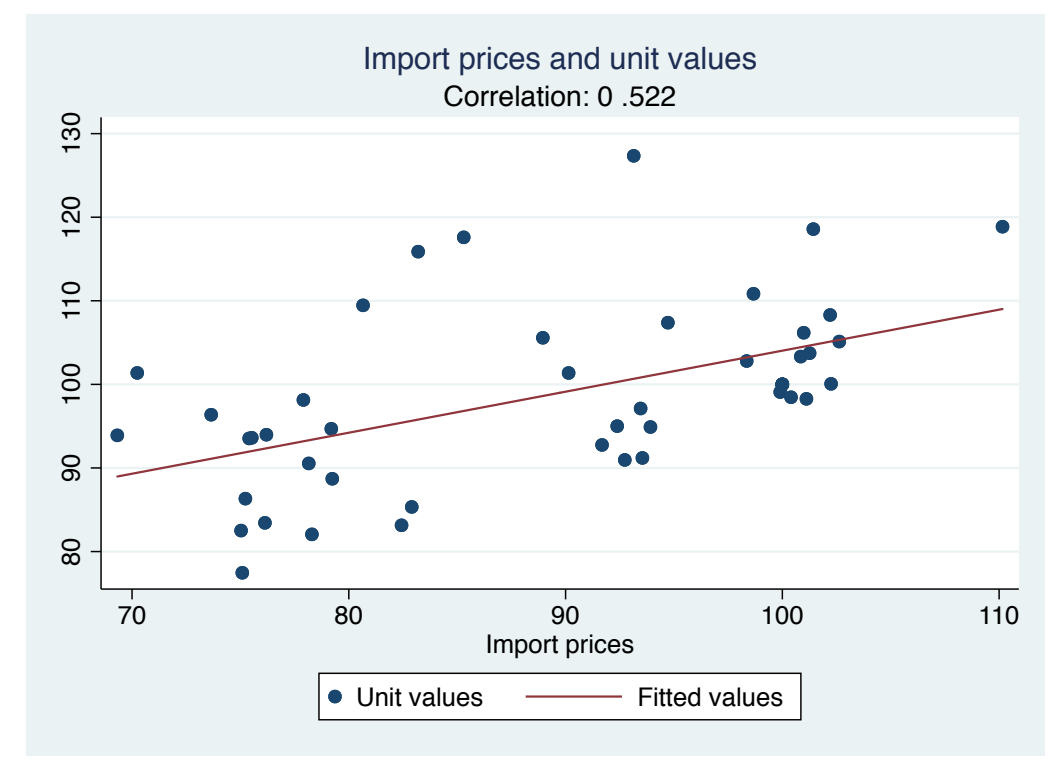

Figure 1: Aggregate import prices and unit values

Source: Eurostat and own calculations. Import prices are aggregate import price indexes from

Eurostat and unit values are calculated from COMEXT. The sample contains data for

Germany, Finland, France, Greece and the Netherlands for our sample period (1996-2006).

From the unit values, import price indexes were calculated using the same base year (1996) as used for consumer price indexes. In addition, we have merged import protection data with our import unit value data. This was provided also in HS1996 classification from the World BankUNCTAD WITS database system, supplemented with OECD/GTAP data on protection for food sectors. Applied average tariff rates were used as a measure of import protection (as a robustness check, we also used weighted average applied tariffs). Since the import data were provided in US dollars, using exchange rate data from the IMF, we transformed dollar denominated import prices to euros. Thus calculating unit values and applying import protection and exchange rates, the landed price of imported products were obtained.

The data on consumer prices (HICP, harmonized index of consumer prices) were obtained from EUROSTAT at detailed product level. Prices as indexes with all indexes being based to the year 2005 were provided in the COICOP classification, which is a more aggregate classification 
than HS6. We re-benchmarked the base year to the first year of our dataset, 1996.

Producer prices were calculated similarly to import prices as unit values of sold production. Value and quantity data on sold production in each member state at product level were obtained from EUROSTAT's PRODCOM database. This database contains data at 8-digit product level provided in the PRODCOM classification. From the value and quantity data, unit values were calculated and then from the unit values, the corresponding producer price index, $P_{H}$, was obtained $(1996=100)$. The PRODCOM dataset has its own classification, and concordances are provided by EUROSTAT to match this data into the HS classification in which the trade data were obtained. Given that the PRODCOM classification changes every year, the concordance was somewhat complex, the procedure used to match products is described in details in the supplementary Annex.

In this paper we focus on final goods which allows us to compare pass-through to consumer and producer prices in a unified framework. Thus we distinguish final goods from intermediate goods and restrict the products in our sample to consumer goods. In order to do this, we follow Bekkers, et al. (2012) and we use a mapping from HS6 product level data according to intermediate vs final use, based on a classification scheme developed for the recent update to the EU-KLEMS database, known as the World Input Output Database or WIOD (further details on this can be found in the supplementary Annex). In order to be able to merge trade and production data with consumer price data, which are reported in different product classifications, we mapped HS1996 into COICOP classification (further details of this mapping process are also provided in the supplementary Annex).

At the end of the data consolidation and mapping process outlined above, we are left with three different price variables in our panel dataset for the euro area member countries over the period 1996-2006. Each price variable is an index of prices with 1996 being the base year $(1996=100) . P_{C}$ is the consumer price index. $P_{M}$ is the corresponding landed price of imports which is calculated from import unit values by applying the applied tariff rates and exchange rates, and calculating the price index $(1996=100) .{ }^{9}$ Finally, $P_{H}$ is the producer price index obtained from unit values of sold domestic production. In addition, as an IV variable we use

\footnotetext{
${ }^{9}$ Exchange rates were not actually fixed within the future euro area until 1st January 1999. For the first three years of the sample there are some very limited exchange rate fluctuations between some pairs of future member countries. However, these are quite small, and the period was marked by deliberate synchronization of monetary policy. Values in our sample are converted with actual rates.
} 
the import price index of the United States $\left(P_{m} U S\right)$ which was constructed with the same procedure as the import price variable $P_{M} .{ }^{10}$

\subsubsection{Retail and distribution sector specific variables}

In order to measure market power in the distribution sector, we use an indicator measuring retail distribution competition from the OECD. The information summarised by the indicator is collected using scoring algorithm on rules, regulations and market conditions by member country officials and OECD experts. Several sub-indicators are calculated using a bottom-up approach in which the regulatory data are quantified using an appropriate scoring algorithm and then aggregated into a summary indicator. The resulting indicator is a sector specific measure concentrating on retail distribution and it is available for 1998, 2003, and 2008. The indicator measures the level of competition in retail distribution, thus providing us with a proxy for margins applied by firms in retail and distribution.

HÃ j, J.et al. (2007) calculate mark-ups on average cost with sectoral data for 17 OECD countries that cover the period 1975 - 2002 and then combine these with the OECD indicators of product market regulation to check whether regulatory policies that are more conducive to competition are related to lower margins. They find that the association between the country average of mark-ups for non-manufacturing and regulations that restrict competition appears to be strong. More precisely, by means of simple regressions, they find that product market regulations that are less conducive to competition are positively and significantly correlated with mark-ups across countries, especially in non-manufacturing. These findings provide empirical evidence that these OECD indexes can be used as a proxy for distribution margin.

The OECD index we use is a composite indicator, based on 10 different sub-indicators measuring the level of competition in the retail distribution, such as price controls, barriers to entry, operation restrictions, license requirements, protection of existing firms among others (see further information on the methodology of the index construction in Conway and Nicoletti (2006)). We interpolate the missing years to obtain coverage for all years between 1996 to 2006 .

Figure 2 shows the value of the indicator by country over 1996-2006 (note that the higher the value of the indicator the lower the level of competition). As can be seen on the figure,

\footnotetext{
${ }^{10}$ We deflate all prices with the general country-specific price index to control for factors influencing all prices simultaneously in the specifications where we do not include time fixed effects.
} 


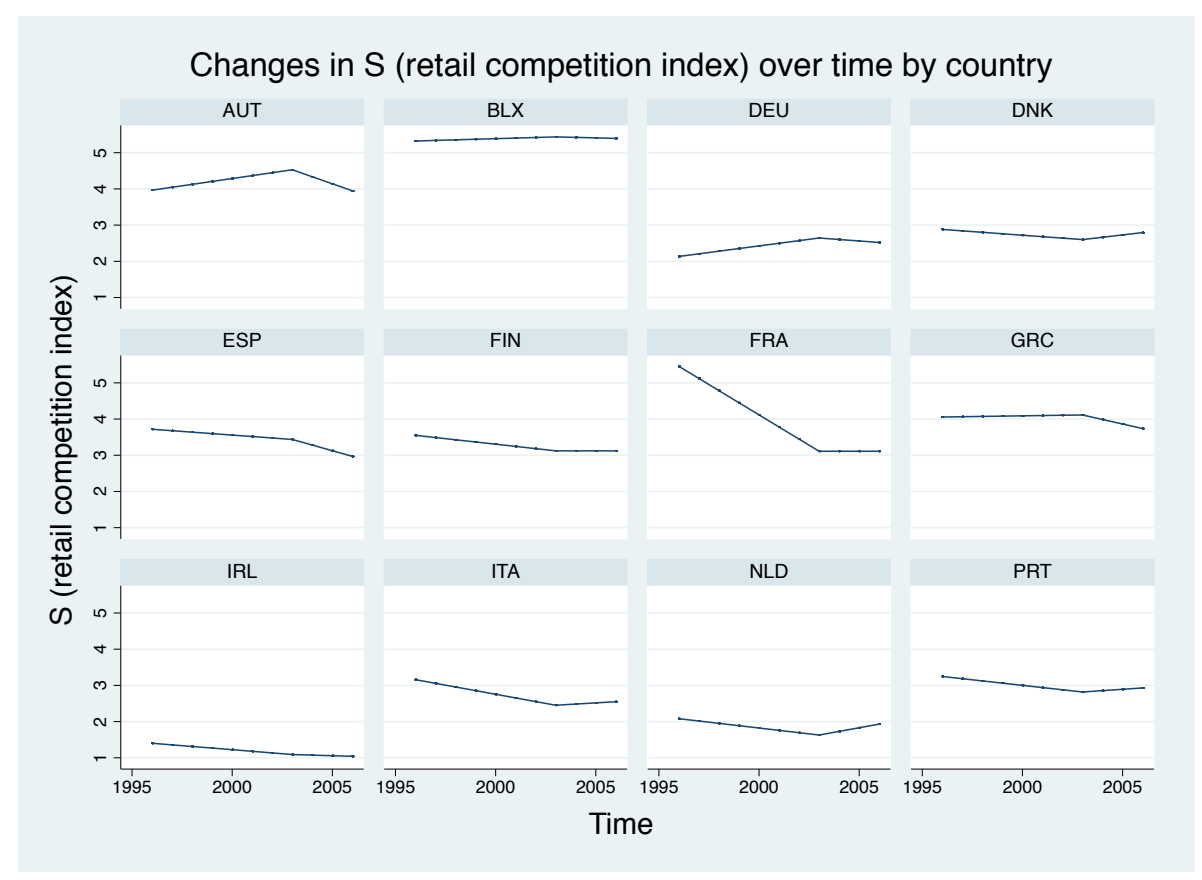

Figure 2: Retail competition index, change over time by country

Note: The higher the value of $S$ the lower the level of competition.

Source: OECD and own calculations.

there is quite a wide variation between countries included in our sample, with Ireland having the highest level of competition in retail distribution while Belgium-Luxembourg the lowest on average over the period. In addition, in all countries in our sample there are changes in the value of the index over time. To illustrate what kind of regulatory changes would result in a change in the value of the index, we take the example of Austria. In the case of Austria, there was first an increase in the index indicating lower level of competition in the sector, which was followed by a decrease. The underlying cause was a number of changes in the regulatory environment effecting the retail and distribution sectors. Some examples of these over time changes include a change from 1998 to 2003 whereby existing firms were better protected by professional bodies or representatives of trade and commercial interests being involved in licensing decisions. This was abandoned again by 2008. In addition, while there was no price control on retail prices in 1998, by 2003 price controls were introduced for tobacco and pharmaceuticals. Furthermore, by 2008 shop opening hours were regulated at national level, while before these were regulated by national, state/provincial, and local level. All other countries also implemented various changes during the period in regulations reflected by the changes in the value of the index. 
As a robustness check, we also use another OECD index, the OECD indicator of regulation impact, which measures the potential costs of anti-competitive regulation in selected non-manufacturing sectors (including retail and wholesale) on sectors of the economy that use the output of non-manufacturing sectors as intermediate inputs in the production process (see Conway et al (2005) and Conway and Nicoletti (2006) for more details). Hence this provides a proxy for anti-competitive behaviour in non-manufacturing sectors including retail and wholesale. The index is available for every year over our sample. This is a less direct measure for distribution market power as it includes also other sectors, nevertheless it can serve as a robustness check for our estimates. The index has a $89 \%$ correlation over the whole sample with our main variable measuring distribution competition, with the yearly correlation ranging from $81 \%$ (in 2006) to $94 \%$ (in 1997).

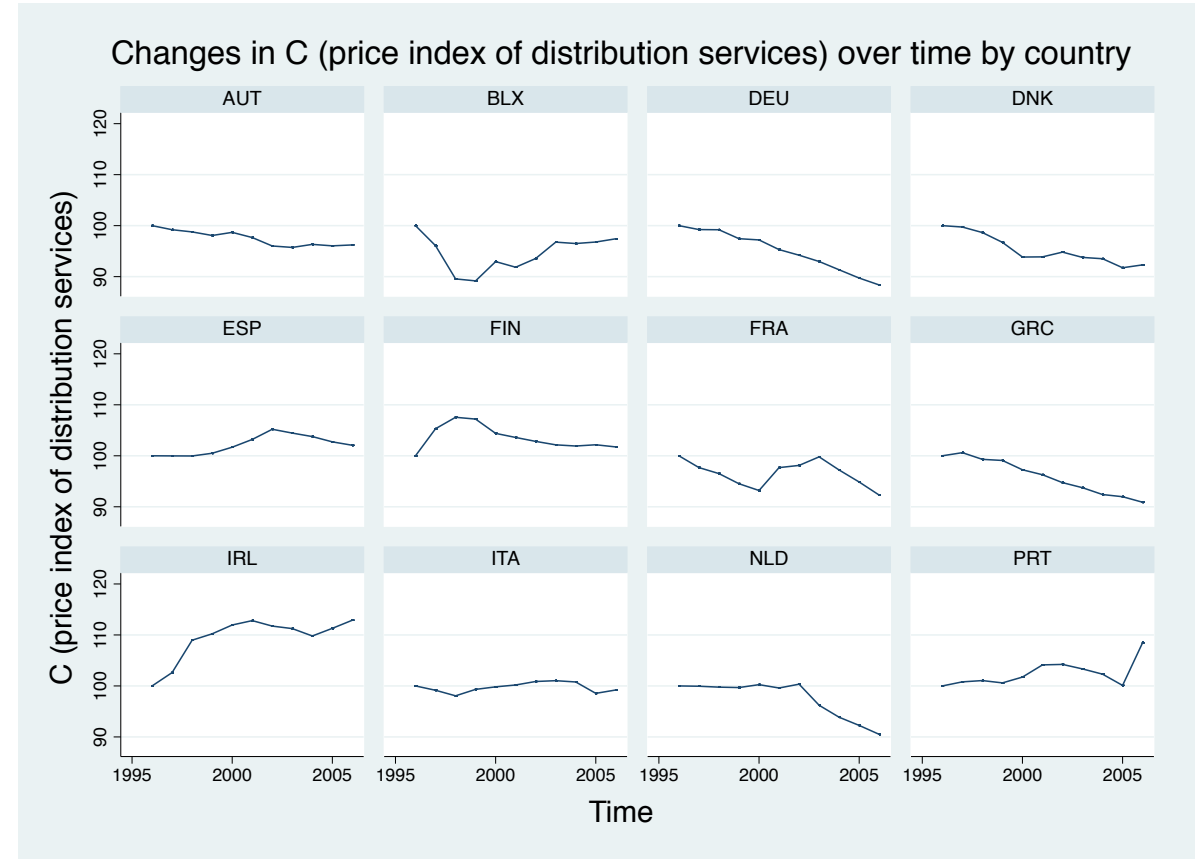

Figure 3: Distribution price index, change over time by country Source: OECD and own calculations.

As a measure of price of margin services $\varsigma$ (or distribution costs) we use again data from WIOD which contains services price data for wholesale and retail sectors. More specifically, we use country-specific yearly price index of wholesale and retail services from WIOD, from which we calculate a country-specific yearly average of wholesale and retail services price index. Figure 3 shows how the resulting variable changes over time and across countries. The resulting measure 
of distribution costs has a $-44 \%$ correlation with our measure of distribution sector competition (this measure is higher the lower the competition). The negative correlation can be an indication of potentially larger distribution firms with larger margins having lower distribution costs.

Table 6 provides descriptive statistics (providing information on the mean, standard deviation, min and max values) for the variables used in the empirical analysis. ${ }^{11}$

\subsubsection{Additional control variables}

As a robustness check, we run regressions distinguishing differentiated goods. To be able to do this, we use Rauch (1999) classification of goods. Rauch (1999) identifies goods which are differentiated goods, reference priced, and goods traded on an organized exchange. In order to distinguish differentiated goods we created a dummy variable which is one for differentiated goods and 0 otherwise .

In addition, we also include further control variables in the regressions which might have an influence on pass-through rates. In particular, we obtain energy price indexes by country and year (aggregate energy price index in euros), country-level rental price index, and country-level annual average wages. All these variables were obtained from OECD.

\subsection{Main results}

Table 1 presents results for consumer and producer price pass-through rates based on estimating equations (17) and (18). Both specifications presented in the table include country-product specific fixed effects, while results presented in the last three columns also include time fixed effects in addition to the country-product fixed effects (the first stage results are presented only for the equation where $\ln \left(P_{m}\right)$ is the dependent variable, in third and last columns).

The results on the interaction effects indicate that a higher degree of market power in the distribution, $S$ (proxied here by the OECD index measuring the level of competition in retail with the index being higher the less competition there is) leads to lower pass-through both for consumer and producer prices. One possible explanation for this finding is that distributors absorb some of the price fluctuations in their own margin hence lessening the pass-through (as has been found also by for example Devereux et al (2003), Devereux and Engel (2003)). The

\footnotetext{
11 The number of observations included in our sample is summarized by country, year and product in table 7 table 8 and table 9 .
} 
Table 1: Pass-through of import prices to consumer and producer prices

\begin{tabular}{|c|c|c|c|c|c|c|}
\hline & \multicolumn{2}{|c|}{ No year f.e. } & \multirow[b]{2}{*}{ First stage } & \multicolumn{2}{|c|}{ With year f.e. } & \multirow[b]{2}{*}{ First stage } \\
\hline & $\operatorname{lnPc}$ & $\operatorname{lnPh}$ & & $\operatorname{lnPc}$ & $\operatorname{lnPh}$ & \\
\hline $\operatorname{lnPm}$ & $\begin{array}{c}0.896 \\
(0.066)^{* * *}\end{array}$ & $\begin{array}{c}0.828 \\
(0.170)^{* * *}\end{array}$ & & $\begin{array}{c}0.739 \\
(0.042)^{* * *}\end{array}$ & $\begin{array}{c}0.929 \\
(0.375)^{* *}\end{array}$ & \\
\hline $\ln C$ & $\begin{array}{c}0.562 \\
(0.055)^{* * *}\end{array}$ & & $\begin{array}{c}1.395 \\
(0.110)^{* * *}\end{array}$ & $\begin{array}{c}0.458 \\
(0.142)^{* * *}\end{array}$ & & $\begin{array}{c}-0.197 \\
(0.066)^{* * *}\end{array}$ \\
\hline $\ln S$ & $\begin{array}{c}1.232 \\
(0.228)^{* * *}\end{array}$ & $\begin{array}{c}2.481 \\
(0.714)^{* * *}\end{array}$ & $\begin{array}{c}0.859 \\
(0.057)^{* * *}\end{array}$ & $\begin{array}{c}0.935 \\
(0.404)^{* *}\end{array}$ & $\begin{array}{c}2.891 \\
(1.073)^{* * *}\end{array}$ & $\begin{array}{c}0.012 \\
(0.050)\end{array}$ \\
\hline $\operatorname{lnPm} * \ln S$ & $\begin{array}{l}-0.247 \\
(0.051)^{* * *}\end{array}$ & $\begin{array}{l}-0.570 \\
(0.159)^{* * *}\end{array}$ & & $\begin{array}{l}-0.194 \\
(0.089)^{* *}\end{array}$ & $\begin{array}{l}-0.672 \\
(0.235)^{* * *}\end{array}$ & \\
\hline $\operatorname{lnPm} * \ln C$ & $\begin{array}{c}-0.104 \\
(0.015)^{* * *}\end{array}$ & & & $\begin{array}{l}-0.041 \\
(0.035)\end{array}$ & & \\
\hline $\operatorname{lnPmUS}$ & & & $\begin{array}{l}-0.006 \\
(0.005)\end{array}$ & & & $\begin{array}{l}-0.006 \\
(0.004)\end{array}$ \\
\hline $\operatorname{lnPmUS*} \ln S$ & & & $\begin{array}{c}0.002 \\
(0.010)\end{array}$ & & & $\begin{array}{l}-0.000 \\
(0.008)\end{array}$ \\
\hline $\operatorname{lnPmUS*} \operatorname{lnC}$ & & & $\begin{array}{c}0.012 \\
(0.003)^{* * *}\end{array}$ & & & $\begin{array}{c}0.004 \\
(0.002)^{* *}\end{array}$ \\
\hline$R^{2}$ & 0.64 & 0.49 & 0.48 & 0.53 & 0.50 & 0.59 \\
\hline$N$ & 4,724 & 4,724 & 4,724 & 4,724 & 4,724 & 4,724 \\
\hline $\begin{array}{l}\text { Country-product f.e. } \\
\text { Year f.e. }\end{array}$ & $\begin{array}{l}\text { Yes } \\
\text { No }\end{array}$ & & & $\begin{array}{l}\text { Yes } \\
\text { Yes } \\
\end{array}$ & & \\
\hline $\begin{array}{l}\text { test: } P c: \ln P m=P h: \ln P m \\
p \text { value }\end{array}$ & $\begin{array}{c}0.14 \\
0.707\end{array}$ & & & $\begin{array}{c}0.25 \\
0.614\end{array}$ & & \\
\hline
\end{tabular}

The dependent variables are $\ln \left(P_{c}\right)$ which is the log of the consumer price index, and $\ln \left(P_{h}\right)$, the $\log$ of producer price index. $\ln \left(P_{m}\right)$ is the log of the landed import price index, $\ln (S)$ is a measure of distribution sector margin (the higher the value the lower the level of competition/higher margin), $\ln (C)$ is the price index of distribution services. The table presents results of instrumental variable estimation with a three-stage estimation for systems of simultaneous equations. The instrument used for $\ln \left(P_{m}\right)$ is the log of US' import price index. First stage results are presented for the equation where the dependent variable is $\left(\ln \left(P_{m}\right)\right.$. There are two additional first stage results due to interaction terms, and additional results table for all first stage results are available upon request from the authors. The last two rows of the table show test results on equality of the pass-through coefficient for consumer and producer prices. Standard errors are presented in parentheses. 
higher margins they have, the more scope there is for dampening pass-through. In addition, we find that distribution costs also tend to lessen consumer price pass-through, although the interaction effects are significant only when no year fixed effects are included in the regression. In fact distribution costs could both lessen or increase pass-through (see Goldberg and Campa (2010) who find that distribution costs can both dampen or magnify exchange rate pass-through into consumer prices).

As we have complex interaction effects, it is informative to look at the marginal effects for the pass-through rates at different values of the $S$ and $C$ variables. Marginal effects at low values of $S$ and $C$ variables (defined as one standard deviation below the mean), at mean values, and at high values of $S$ and $C$ (defined as one standard deviation above the mean) are presented in Table 2. The table also provides results of a test on equality of the pass-through rate for consumer and producer prices. As market power in the distribution and costs of these services become higher, the pass-through becomes smaller, with producer price pass-through being more sensitive to these changes. At higher level of competition in distribution (with $S$ one standard deviation lower than average) and lower cost (again one standard deviation below the mean), consumer pass-through is estimated to be around $41 \%$ while producer pass-through $45 \%$ (in the specification when time fixed effects are included). In other words, if there is a $100 \%$ increase in landed import prices, consumer prices are estimated to increase by about $41 \%$ while producer prices by $45 \%$ when both distribution margins and costs are below average. At average values consumer price pass-through decreases but becomes higher than producer price pass-through at around 33\%, while producer price pass-through is estimated to be around $19 \%$. These results indicate that distribution margins can significantly dampen both producer and consumer price pass-through and that producer price pass-through varies more as distribution margin and distribution costs change.

\subsection{Robustness}

\subsubsection{Additional control variables}

Results using additional country-time varying control variables that may be correlated with distribution sector market power but also exert an independent effect on pass-through are included in the specification presented in the first two columns of Table 3. More specifically, we 
Table 2: Marginal effects of pass-through

\begin{tabular}{|l|ccc|ccc|}
\hline & \multicolumn{3}{|c}{ No year f.e. } & \multicolumn{3}{c}{ With year f.e. } \\
\hline & at low C and S & at means & at high C and S & at low C and S & at means & at high C and S \\
\hline Pc:lnPm & 0.246 & 0.146 & 0.046 & 0.412 & 0.334 & 0.256 \\
& $(7.75)^{* *}$ & $(5.27)^{* *}$ & $(1.29)$ & $(3.51)^{* *}$ & $(2.86)^{* *}$ & $(0.125)^{*}$ \\
Ph:lnPm & 0.418 & 0.199 & -0.021 & 0.446 & 0.188 & -0.071 \\
& $(5.67)^{* *}$ & $(3.34)^{* *}$ & $(0.22)$ & $(1.59)$ & $(0.71)$ & $(0.275)$ \\
\hline$N$ & 4,724 & 4,724 & 4,724 & 4,724 & 4,724 & 4,724 \\
test: Pc:lnPm $=$ Ph:lnPm & 5.01 & 0.71 & 0.46 & 0.01 & 0.29 & 1.32 \\
p value & 0.025 & 0.400 & 0.496 & 0.906 & 0.589 & 0.251 \\
\hline
\end{tabular}

* $p<0.05 ;{ }^{* *} p<0.01$

Marginal effects are based on estimates presented in Table 1. Pc:lnPm is for marginal effects of the pass-through for consumer prices, and $\mathrm{Ph}: \ln \mathrm{Pm}$ is for producer prices. Marginal effects are evaluated at low $\mathrm{C}$ and $\mathrm{S}$ values (one standard deviation below the mean), at mean, and at high $\mathrm{C}$ and $\mathrm{S}$ values (one standard deviation above the mean). The last two rows of the table show test results on equality of the marginal effects of pass-through coefficient for consumer and producer prices. Standard errors are presented in parentheses.

include the log of average wages in the country, the average energy price and average rental price index. These additional variables are correlated with the cost of distribution services $C$, most importantly wages (there is a $74 \%$ correlation between the $\log$ of wages and $\operatorname{lnC}$ ). As we include these variables, $\operatorname{lnC}$ and its interaction effect become insignificant, nevertheless the interaction effects and sign and significance of distribution margin remains similar to previous results.

In the last two columns of Table 3 the import price variable is further interacted with a dummy for differentiated goods (taking the value of one for differentiated goods). Similarly to the previous specification, we include year fixed effects in addition to country-product fixed effects. The interaction effect is positive, although significant only in the consumer pass-through. Thus the pass-through for differentiated goods is higher than for more homogenous goods. The coefficients and significance on other explanatory variables remain very similar to those presented in Table 1 , highlighting the importance of distribution margin dampening the passthrough rates both to consumer and producer prices.

\subsubsection{Alternative measure of market power}

In this section we present results using an alternative measure of market power. This alternative index is also obtained from the OECD and measures the cost of anti-competitive regulation in non-manufacturing sectors, which indirectly can provide a proxy for the level of competetitive environment in services including retail and wholesale. The results using this alternative measure 
Table 3: Robustness checks; additional controls

\begin{tabular}{|c|c|c|c|c|}
\hline & \multicolumn{2}{|c|}{ Additional control variables } & \multicolumn{2}{|c|}{ Distinguishing differentiated goods } \\
\hline & $\ln \mathrm{Pc}$ & $\ln \mathrm{Ph}$ & $\ln \mathrm{Pc}$ & $\ln \mathrm{Ph}$ \\
\hline $\operatorname{lnPm}$ & $\begin{array}{c}0.592 \\
(0.111)^{* * *}\end{array}$ & $\begin{array}{c}1.436 \\
(0.405)^{* * *}\end{array}$ & $\begin{array}{c}0.742 \\
(0.038)^{* * *}\end{array}$ & $\begin{array}{c}0.921 \\
(0.425)^{* *}\end{array}$ \\
\hline $\ln C$ & $\begin{array}{c}0.124 \\
(0.177)\end{array}$ & & $\begin{array}{c}0.616 \\
(0.144)^{* * *}\end{array}$ & \\
\hline $\ln S$ & $\begin{array}{c}1.195 \\
(0.414)^{* * *}\end{array}$ & $\begin{array}{c}3.499 \\
(1.208)^{* * *}\end{array}$ & $\begin{array}{c}0.910 \\
(0.366)^{* *}\end{array}$ & $\begin{array}{c}2.854 \\
(1.078)^{* * *}\end{array}$ \\
\hline $\operatorname{lnPm} * \ln S$ & $\begin{array}{c}-0.257 \\
(0.091)^{* * *}\end{array}$ & $\begin{array}{c}-0.812 \\
(0.267)^{* * *}\end{array}$ & $\begin{array}{c}-0.187 \\
(0.080)^{* *}\end{array}$ & $\begin{array}{c}-0.664 \\
(0.237)^{* * *}\end{array}$ \\
\hline $\operatorname{lnPm} * \ln C$ & $\begin{array}{c}0.008 \\
(0.040)\end{array}$ & & $\begin{array}{c}-0.078 \\
(0.035)^{* *}\end{array}$ & \\
\hline lnwage & $\begin{array}{c}0.093 \\
(0.059)\end{array}$ & $\begin{array}{c}0.039 \\
(0.134)\end{array}$ & & \\
\hline energyprice & $\begin{array}{c}0.001 \\
(0.000)^{* *}\end{array}$ & $\begin{array}{c}0.002 \\
(0.001)\end{array}$ & & \\
\hline rents & $\begin{array}{c}0.002 \\
(0.000)^{* * *}\end{array}$ & $\begin{array}{c}0.005 \\
(0.001)^{* * *}\end{array}$ & & \\
\hline $\operatorname{lnPm} *$ differentiated goods & & & $\begin{array}{c}0.160 \\
(0.075)^{* *}\end{array}$ & $\begin{array}{c}0.019 \\
(0.212)\end{array}$ \\
\hline $\begin{array}{l}R^{2} \\
N\end{array}$ & $\begin{array}{c}0.51 \\
4,724\end{array}$ & $\begin{array}{c}0.43 \\
4,724\end{array}$ & $\begin{array}{c}0.61 \\
4,724\end{array}$ & $\begin{array}{c}0.50 \\
4,724\end{array}$ \\
\hline $\begin{array}{l}\text { Country-product f.e. } \\
\text { Year f.e. }\end{array}$ & $\begin{array}{l}\text { Yes } \\
\text { Yes }\end{array}$ & & $\begin{array}{l}\text { Yes } \\
\text { Yes }\end{array}$ & \\
\hline $\begin{array}{l}\text { test: } P c: \ln P m=P h: \ln P m \\
\text { p value }\end{array}$ & $\begin{array}{c}3.98 \\
0.046\end{array}$ & & $\begin{array}{c}0.18 \\
0.674\end{array}$ & \\
\hline
\end{tabular}

The dependent variables are $\ln \left(P_{c}\right)$ which is the log of the consumer price index, and $\ln \left(P_{h}\right)$ which is the $\log$ of producer price index. $\ln \left(P_{m}\right)$ is the log of the landed import price index, $\ln (S)$ is a measure of distribution sector margin (the higher the value the lower the level of competition/higher margin), $\ln (C)$ is the price index of distribution services, lnwage is the log of average wage in the country, energyprice and rents are average energy price and average rental price in the country, differentiated goods is a dummy for differentiated goods. The table presents results of instrumental variable estimation with a three-stage estimation for systems of simultaneous equations. The instrument used for $\ln \left(P_{m}\right)$ is the $\log$ of US' import price index. The last two rows of the table show test results on equality of the pass-through coefficient for consumer and producer prices. Standard errors are presented in parentheses. 
Table 4: Alternative measures of market power

\begin{tabular}{|c|c|c|c|c|}
\hline & \multicolumn{2}{|c|}{ Alternative $\operatorname{lnS}$} & \multicolumn{2}{|c|}{ Marginal effects at means } \\
\hline & $\operatorname{lnPc}$ & $\ln \mathrm{Ph}$ & $\ln \mathrm{Pc}$ & $\operatorname{lnPh}$ \\
\hline $\operatorname{lnPm}$ & $\begin{array}{c}0.806 \\
(0.043)^{* * *}\end{array}$ & $\begin{array}{c}-1.653 \\
(0.547)^{* * *}\end{array}$ & $\begin{array}{c}0.353 \\
(2.95)^{* *}\end{array}$ & $\begin{array}{c}0.468 \\
(0.342)\end{array}$ \\
\hline $\ln \mathrm{C}$ & $\begin{array}{c}1.040 \\
(0.206)^{* * *}\end{array}$ & & & \\
\hline $\ln S$ & $\begin{array}{c}1.875 \\
(0.779)^{* *}\end{array}$ & $\begin{array}{c}9.870 \\
(2.124)^{* * *}\end{array}$ & & \\
\hline $\operatorname{lnPm} * \operatorname{lnS}$ & $\begin{array}{c}-0.459 \\
(0.166)^{* * *}\end{array}$ & $\begin{array}{l}-2.317 \\
(0.447)^{* * *}\end{array}$ & & \\
\hline $\operatorname{lnPm} * \ln C$ & $\begin{array}{c}-0.186 \\
(0.048)^{* * *}\end{array}$ & & & \\
\hline$R^{2}$ & 0.50 & 0.37 & & \\
\hline$N$ & 4,724 & 4,724 & 4,724 & 4,724 \\
\hline $\begin{array}{l}\text { Country-product f.e. } \\
\text { Year f.e. }\end{array}$ & $\begin{array}{l}\text { Yes } \\
\text { Yes }\end{array}$ & & & \\
\hline $\begin{array}{l}\text { test: } \mathrm{Pc}: \ln \mathrm{Pm}=\mathrm{Ph}: \ln \mathrm{Pm} \\
\mathrm{p} \text { value }\end{array}$ & $\begin{array}{l}19.84 \\
0.000\end{array}$ & & $\begin{array}{c}0.13 \\
0.723\end{array}$ & \\
\hline
\end{tabular}

The dependent variables are $\ln \left(P_{c}\right)$ which is the log of the consumer price index, and $\ln \left(P_{h}\right)$ which is the $\log$ of producer price index. $\ln \left(P_{m}\right)$ is the log of the landed import price index, $\ln (S)$ here is an OECD index measuring competitiveness in non-manufacturing sectors which we use as a proxy for wholesale and retail margin (higher value indicates lower the level of competition/higher margin), $\ln (C)$ is an index of the price of distribution services. The table presents results of instrumental variable estimation with a three-stage estimation for systems of simultaneous equations. The instrument used for $\ln \left(P_{m}\right)$ is the $\log$ of US' import price index. The last two rows of the table show test results on equality of the pass-through coefficient for consumer and producer prices. Marginal effects were calculated at the mean. Standard errors are presented in parentheses.

of market power is presented in Table 4, with the second two columns showing the marginal effects for consumer and producer pass-through evaluated at the means.

The interaction effects are significant and negative in both the producer and consumer pass-through regressions similarly to the previous results, indicating again that higher cost of distribution or less competitive environment in the distribution sector results in lower passthrough rates. Looking at the marginal effects, price pass-through to consumer prices are very close to those in our main specification presented in Table 2, while the producer price passthrough is higher, about $47 \%$ at the mean values of $\mathrm{S}$ and C.

\subsubsection{Exchange rates, tariffs and before the border import prices}

Some of the previous literature on pass-through showed that estimated pass-through of import prices into domestic prices can be different for tariff-induced price changes from exchange rate induced price changes (see for example Fitzgerald and Haller (2014)). Hence as a robustness 
Table 5: Pass-through with separating out exchange-rate and tariffs

\begin{tabular}{|c|c|c|c|c|}
\hline & \multicolumn{2}{|c|}{$\begin{array}{l}\text { Separate price pass-through } \\
\text { with weighted tariffs }\end{array}$} & \multicolumn{2}{|c|}{$\begin{array}{l}\text { Separate price pass-through } \\
\text { with unweighted tariffs }\end{array}$} \\
\hline & $\operatorname{lnPc}$ & $\ln \mathrm{Ph}$ & $\operatorname{lnPc}$ & $\operatorname{lnPh}$ \\
\hline $\operatorname{lnPm}$ & $\begin{array}{c}0.910 \\
(0.292)^{* * *}\end{array}$ & $\begin{array}{l}2.088 \\
(0.621)^{* * *}\end{array}$ & $\begin{array}{c}0.754 \\
(0.256)^{* * *}\end{array}$ & $\begin{array}{l}1.977 \\
(0.576)^{* * *}\end{array}$ \\
\hline $\ln C$ & $\begin{array}{c}0.605 \\
(0.184)^{* * *}\end{array}$ & & $\begin{array}{l}0.607 \\
(0.191)^{* * *}\end{array}$ & \\
\hline $\ln S$ & $\begin{array}{l}2.178 \\
(0.839)^{* * *}\end{array}$ & $\begin{array}{l}4.330 \\
(1.646)^{* * *}\end{array}$ & $\begin{array}{l}2.302 \\
(0.853)^{* * *}\end{array}$ & $\begin{array}{c}3.723 \\
(1.489)^{* *}\end{array}$ \\
\hline $\ln P m^{*} \ln S$ & $\begin{array}{c}-0.516 \\
(0.183)^{* * *}\end{array}$ & $\begin{array}{c}-1.129 \\
(0.410) * * *\end{array}$ & $\begin{array}{c}-0.528 \\
(0.188) * * *\end{array}$ & $\begin{array}{c}-0.982 \\
(0.369)^{* * *}\end{array}$ \\
\hline $\ln P m^{*} \ln C$ & $\begin{array}{c}-0.114 \\
(0.078)\end{array}$ & & $\begin{array}{c}-0.091 \\
(0.076)\end{array}$ & \\
\hline $\operatorname{lnER}$ & $\begin{array}{c}0.094 \\
(0.064)\end{array}$ & $\begin{array}{c}-0.340 \\
(0.076)^{* * *}\end{array}$ & $\begin{array}{l}0.145 \\
(0.052)^{* * *}\end{array}$ & $\begin{array}{l}-0.327 \\
(0.069)^{* * *}\end{array}$ \\
\hline $\ln \mathrm{Tw}$ & $\begin{array}{c}-0.365 \\
(0.082)^{* * *}\end{array}$ & $\begin{array}{c}-0.395 \\
(0.193)^{* *}\end{array}$ & & \\
\hline $\ln \mathrm{T}$ & & & $\begin{array}{c}-0.698 \\
(0.266)^{* * *}\end{array}$ & $\begin{array}{c}-1.512 \\
(0.566)^{* * *}\end{array}$ \\
\hline $\begin{array}{l}R^{2} \\
N\end{array}$ & $\begin{array}{c}0.62 \\
4,720\end{array}$ & $\begin{array}{c}0.34 \\
4,720\end{array}$ & $\begin{array}{c}0.61 \\
4,720\end{array}$ & $\begin{array}{c}0.35 \\
4,720\end{array}$ \\
\hline $\begin{array}{l}\text { Country-product f.e. } \\
\text { Year f.e. }\end{array}$ & $\begin{array}{l}\text { Yes } \\
\text { No }\end{array}$ & & $\begin{array}{l}\text { Yes } \\
\text { No }\end{array}$ & \\
\hline $\begin{array}{l}\text { test: } \mathrm{Pc}: \ln \mathrm{Pm}=\mathrm{Ph}: \ln \mathrm{Pm} \\
\mathrm{p} \text { value }\end{array}$ & $\begin{array}{c}2.98 \\
0.084\end{array}$ & & $\begin{array}{c}3.77 \\
0.052\end{array}$ & \\
\hline
\end{tabular}

The dependent variables are $\ln \left(P_{c}\right)$ which is the $\log$ of the consumer price index, and $\ln \left(P_{h}\right)$ which is the $\log$ of producer price index. $\ln \left(P_{m}\right)$ is the $\log$ of the landed import price index, $\ln (S)$ is a measure of distribution sector margin (the higher the value the lower the level of competition/higher margin), $\ln (C)$ is the price index of distribution services, $\ln (E R)$ is the yearly exchange rate, $\ln (T)$ are unweighted product level tariffs, and $\ln \left(T_{w}\right)$ are weighted tariffs. The table presents results of instrumental variable estimation with a three-stage estimation for systems of simultaneous equations. The instrument used for $\ln \left(P_{m}\right)$ is the log of US' import price index. The last two rows of the table show test results on equality of the pass-through coefficient for consumer and producer prices. Marginal effects were calculated at the mean. Standard errors are presented in parentheses.

check, we run regressions without applying exchange rate changes and tariff changes on import prices and instead include these variables in the regressions separately.

Results are presented in Table 5 with the first two columns using trade weighted tariffs while the second two columns unweighted tariffs. These specifications do not include time fixed effects as the countries in our sample have the same exchange rates (and as we have yearly data this would result in multicollinearity). The sign and significance of our main variables of interest are similar to those presented in table 1 with these results again confirming that distribution margins can significantly dampen both producer and consumer price pass-through. ${ }^{12}$

\footnotetext{
${ }^{12}$ We also run regresions with similar to our main specifications, with the exchange rate variable as an IV (without including year fixed effects as for the euro area year fixed effects would result in multicollinearity problem).
} 


\section{Summary}

In this paper, we have developed a theoretical framework in which the distribution sector exercises market power vis-à-vis consumers and also vis-à-vis domestic and foreign suppliers of goods. Within this framework, a double margin mechanism links landed import prices to consumer prices and competing producer prices. This mechanism is a function of varying degrees of market power and allows us to gain insights into how changes in landed import prices will pass-through into domestic producer and consumer prices.

Using this framework, we have estimated pass-through rates from landed import prices to consumer and producer prices in the euro area countries over the period 1996-2006 while controlling for the influence of market power in distribution and distribution costs. We depart from the recent literature by focusing jointly on both producer and consumer prices, and by stressing border prices whereby the variation in the pass-through differences between countries in our sample can come from various sources including variations in tariffs and exchange rate changes. We also concentrate on final goods which allows us to coherently compare consumer and producer pass-through in an integrated framework.

Results indicate that only a portion of import price changes translate into consumer and producer price changes limiting the potential benefits from tariff liberalization. One important factor reducing the pass-through rate based on our results is market power in the distribution sector. We obtain a pass-through rate of around $41 \%$ for consumer prices, and about $45 \%$ for producer prices when there is more competition than average in the distribution sector and the cost of distribution services is lower than average (these are marginal effects evaluated at one standard deviation below the mean of these variables). As these services become more costly and there is less competition in distribution services, pass-through decreases, with producer price pass-through being dampened more with increasing distribution margins and distribution costs.

The sign and significance of all coefficients remain the same. The results are presented in the supplementary Annex in Table 1. 


\section{References}

Antoniades, A. And Zaniboni, N. (2016) ."Exchante rate pass-through into retail prices. "International Economic Review 57: 1425-1447.

Mary Amiti, Oleg Itskhoki, Jozef Konings. (2014)."Importers, exporters, and exchange rate disconnect." American Economic Review 104(7):1942-1978.

Auer, R. And A. M.Fischer. (2010)."The effect of low-wage import competition on U.S. inflationary pressure." The Journal of Monetary Economics 57: 491-503.

Auer, Raphael A and Schoenle, Raphael S (2016)."Market structure and exchange rate pass-through. "Journal of International Economics 98: 60-77.

Auer, Raphael and Burstein, Ariel and Lein, Sarah M. (2017) ."Price and Consumption Responses to Large Exchange Rate Shocks: Evidence from the 2015 Appreciation in Switzerland "mimeo

Bacchetta, P and E. Van Wincoop (2003), "Why do Consumer Prices react Less than Import Prices to Exchange Rates?" Journal of the European Economic Association 1(2-3) 662-670.

Bekkers, E., J.F. Francois and M. Manchin (2012). "Importer Prices, Income, and Income Inequality." "European Economic Review 56(4): 848-869.

Berger, D., Faust, J., Rogers, J. H., and Steverson, K. (2012). "Border prices and retail prices. " Journal of international Economics, 88(1), 62-73.

Berman,N., P. Martin and T. Mayer. (2012). "How do Different Exporters React to Exchange Rate Changes? Theory, Empirics and Aggregate Implications. "The Quarterly Journal of Economics 127(1), 437-492.

Beveren, I Van, Bernard, AB and Vandenbussche, H (2012). "Concording EU trade and production data over time. "National Bank of Belgium Working Paper No 239.

Bloningen, B. A. And S. E. Haynes (2002). "Antidumping Investigations of the PassThrough of Antidumping Duties and Exchange Rates. "American Economic Review 92(4): 1044-1061.

Burstein, A.T., G. Gopinath (2014). "International prices and exchange rates. "In Gita Gopinath, Elhanan Helpman, and Kenneth Rogo , editors, Handbook of International Economics Volume IV. 2014

Campa, J. M. and L. S. Goldberg (2005). "Exchange Rate Pass-Through into Import Prices. "The Review of Economics and Statistics 87: 679-690.

Campa, J. M., L. S. Goldberg and J. M. Gonzalez-Minguez (2005). "Exchange Rate Pass-Through to Import Prices in the Euro Area. "Federal Reserve Bank of New York Staff Report No. 219.

Campa, J. M. And L. S. Goldberg (2006). "Distribution Margins, Imported Inputs and the insensitivity of the CPI to Exchange Rates. "No. w12121. National Bureau of Economic Research, 2006 
Cavallo, Alberto, Brent Neiman, and Roberto Rigobon (2014). "Currency Unions, Product Introductions, and the Real Exchange Rate. "Quarterly Journal of Economics 129 (2) pp. 529-595.

A. Chatterjee, R. Dix-Carneiro, J. Vichyanond (2013). "Multi-product firms and exchange rate fluctuations. "American Economic Journal: Economic Policy 5 (2) (2013), pp. $77-10$.

Chen,N., J. Imbs And A. Scott (2010). "The dynamics of trade and competition. "Journal of International Economics 70:50-62.

Conway, P., V. Janod and G. Nicoletti (2005). "Product Market Regulation in OECD Countries: 1998 to 2003. "OECD Economics Department Working Paper, No 419.

Conway, P. And G. Nicoletti (2006). "Product Market Regulation in the NonManufacturing Sectors of OECD Countries: Measurement and Highlights. "OECD Economics Department Working Paper, No 530.

Corsetti, G. And L. Dedola (2005). "A macroeconomic model of international price discrimination. "Journal of International Economics 67:129-155.

Devereux, M. B. C. Engel and C. Tille (2003). "Exchange Rate Pass-through and the Welfare Effects of the Euro. "International Economic Review 44: 223-242.

Devereux, M. B. , AND C. Engel (2003). "Monetary policy in the open economy revisited: Price setting and exchange-rate flexibility. "The Review of Economic Studies 70(4), 765-783.

Dobson, P. W., And Waterson, M. (2007). "The competition effects of industry-wide vertical price fixing in bilateral oligopoly. "International Journal of Industrial Organization 25(5), 935-962.

Dornbusch, R. (1987). "Exchange Rates and Prices."American Economic Review 97: 93-106.

Feenstra, R.C., J. E. Gagnon And M.M. Knetter (1996). "Market share and exchange rate pass-through in world automobile trade. "Journal of International Economics 40: 187207.

FeinberG, R. (1986). "The Interaction of Foreign Exchange and Market Power Effects on German Domestic Prices. " Journal of Industrial Economics 35:61-70.

FeinberG, R. (1989). "The Effects of Foreign Exchange Movements on U.S. Domestic Prices. "Review of Economics and Statistics 71:505-511.

Feinberg, R. (1991). "The Choice of Exchange-rate Index and Domestic Price Pass-Through. "Journal of Industrial Economics 39:409-420.

Feinberg R. M. and S. Kaplan (1992). "The Response of Domestic Prices to Expected Exchange Rates. "Journal of Business 65(2): 267-280.

FeinberG, R. (1996). "A Simultaneous Analysis of Exchange-Rate pass-through into Prices of Imperfectly Substitutable Domestic and Import Goods. "International Review of Economics and Finance 5:4 407-416.

FEINBERG, R. (2008). "Import price effects on retail prices in the US and abroad: two cases. "Economics Bulletin 13: 1-7. 
FitzGerald, Doireann (2008). "Can trade costs explain why exchange rate volatility does not feed into consumer prices? "Journal of Monetary Economics 55: 606- 628.

Fitzgerald, D and S. Haller (2014). "Pricing-to-Market: Evidence From Plant-Level Prices. "Review of Economic Studies 81 (2): 761-86.

Francois, J.F. And B. Hoekman (2010). "Trade and Policy in Services. "Journal of Economic Literature 48(3): 642-92.

Francois,J. O. Pindyuk, J. Poeschl, R. Stehrer (2010). "WIOD Data on Trade in Goods: Data Issues and Patterns of Trade in Intermediates." paper presented at the World Input Output Database (WIOD) Conference, Vienna.

Francois, J And I. Wooton (2001). "Trade in International Transport Services: The Role of Competition. "Review of International Economics 9(2): 249- 261.

Francois, J And I. Wooton (2010). "Market Structure and Market Access. "World Economy 33(7): 873-893.

Frankel, J., D. Parsley and S.-J. Wei (2012). "Slow pass-through Around the World: A New Import for Developing Countries?"Open Economies Review Volume 23, Issue 2, pp 213-251.

Gaulier G., A. Lahrche-Revil and I. Mejean (2008). "Exchange-rate pass through at the product level." Canadian Journal of Economics 41(2):425-449.

Goldberg, Linda S., and Jose Manuel Campa (2010). "The sensitivity of the CPI to exchange rates: Distribution margins, imported inputs, and trade exposure "The Review of Economics and Statistics 92(2): 392-407.

Goldberg, P. K. And Knetter, M. M. (1997). "Goods Prices and Exchange Rates: What Have We Learned? "Journal of Economic Literature 35: 1243-1272.

Gopinath, G And O. Itskhoki (2010). "Frequency of Price Adjustment and Pass-Through. "The Quarterly Journal of Economics 125(2), 675-727

Gopinath, Gita, Oleg Itskhoki, and Roberto Rigobon (2010). "Currency Choice and Exchange Rate Pass-Through. "American Economic Review 100 (1): 304-36

Gopinath, Gita, and Roberto Rigobon. (2008). "Sticky Borders." Quarterly Journal of Economics 123(2): 531-75

Hellerstein, R. (2008). "Who bears the cost of a change in the exchange rate? Pass-through accounting for the case of beer. "Journal of International Economics 76: 14-32.

Jens HÃ, J, Miguel Jimenez, Maria Maher, Giuseppe Nicoletti, Michael Wise (2007) "Product Market Competition in the OECD Countries: Taking Stock and Moving Forward. "OECD Economics Department Working Papers No. 575.

Hong, Gee Hee, And Nicholas Li (2017)."Market structure and cost pass-through in retail. "Review of Economics and Statistics 99(1), 151-166.

Hummels, D., V. Lugovskyy (2009). "International Pricing in a Generalized Model of Ideal Variety." Journal of Money, Credit and Banking 41(1): 3-33. 
Ihrig, J.E., M. Marazzi And A.D. Rothenberg (2006). "Exchange-Rate Pass-Through in the G-7 Countries."International Finance Discussion Papers, Board of Governors of the Federal Reserve System, No. 851.

Li, Hongbin, Ma, Hong and Xu, Yuan. (2015). "How do exchange rate movements affect Chinese exports? A firm-level investigation "Journal of International Economics 97 (1): 148161.

Mishkin, F.S. (2008). "Exchange Rate Pass-through and Monetary Policy. "NBER Working Paper No.13889.

Richardson, M. (2004). "Trade Policy and Access to Retail Distribution. "Review of International Economics 12: 676-688.

RAfF, H And N. Schmitt (2009). "Buyer Power in International Markets. "Journal of International Economics 79(2), 222-229.

Raff, H And N. Schmitt (2008b). "International Trade with Heterogeneous Retailers. "Mimeo- presented at the 2008 ETSG Conference in Warsaw.

RAUCH, J. (1999), "Networks versus Markets in International Trade", Journal of International Economics 48, pp. 7-35.

Schotт, Peter K. (2004). "Across-Product Versus Within-Product Specialization in International Trade." Quarterly Journal of Economics 119 (2): 647-678.

Strasser, Georg. (2013). "Exchange Rate Pass-Through and Credit Constraints. "Journal of Monetary Economics 60 (1): 25-38.

ZELLner, A. (1962). "An efficient method of estimating seemingly unrelated regressions and tests for aggregation bias. "Journal of the American Statistical Association 57: 348-368.

YANG, J. (1997). "Exchange Rate Pass-Through in U.S. Manufacturing Industries. "Review of Economics and Statistics 79: 95-104. 


\section{Annex tables}

Table 6: Descriptive statistics

\begin{tabular}{rlrrrr}
\hline Variable & Obs & \multicolumn{1}{c}{ Mean } & Std. Dev. & \multicolumn{1}{l}{ Min } & \multicolumn{1}{l}{ Max } \\
\hline$P m$ & 4,724 & 103.679 & 23.765 & 56.957 & 190.035 \\
$P c$ & 4,724 & 106.111 & 12.303 & 19.441 & 197.902 \\
$P h$ & 4,724 & 110.757 & 37.642 & 71.330 & 194.814 \\
$S$ & 4,724 & 3.221 & 1.106 & 1.041 & 5.455 \\
$C$ & 4,724 & 109.713 & 10.862 & 91.727 & 153.157 \\
\hline
\end{tabular}

$P_{m}$ is the landed import price index, $P_{c}$ is the consumer price index, $P_{h}$ is the producer price index, $S$ is a measure of distribution sector margin, $C$ is the price index of distribution services.

Table 7: Annex: Country codes, corresponding country names and number of observations

\begin{tabular}{llrr}
\hline Country name & Country code & No. of observations & Percent \\
\hline Austria & AUT & 340 & 7.2 \\
Belgium-Luxembourg & BLX & 391 & 8.28 \\
Germany & DEU & 466 & 9.86 \\
Denmark & DNK & 423 & 8.95 \\
Spain & ESP & 430 & 9.1 \\
Finland & FIN & 322 & 6.82 \\
France & FRA & 443 & 9.38 \\
Greece & GRC & 406 & 8.59 \\
Ireland & IRL & 356 & 7.54 \\
Italy & ITA & 465 & 9.84 \\
Netherlands & NLD & 316 & 6.69 \\
Portugal & PRT & 366 & 7.75 \\
\hline Total & & 4,724 & 100 \\
\hline
\end{tabular}


Table 8: Annex: Years in the sample and corresponding number of observations

\begin{tabular}{rrr}
\hline Year & No. of observations & Percent \\
\hline 1996 & 474 & 10.03 \\
1997 & 458 & 9.7 \\
1998 & 460 & 9.74 \\
1999 & 456 & 9.65 \\
2000 & 449 & 9.5 \\
2001 & 446 & 9.44 \\
2002 & 440 & 9.31 \\
2003 & 443 & 9.38 \\
2004 & 441 & 9.34 \\
2005 & 420 & 8.89 \\
2006 & 237 & 5.02 \\
\hline
\end{tabular}


Table 9: Annex: Product names, codes and number of observations

\begin{tabular}{|c|c|c|c|}
\hline Product name & COICOP & Freq. & Share \\
\hline Bread and cereals & 111 & 127 & 2.69 \\
\hline Meat & 112 & 127 & 2.69 \\
\hline Fish and seafood & 113 & 116 & 2.46 \\
\hline Milk, cheese and eggs & 114 & 127 & 2.69 \\
\hline Oils and fats & 115 & 126 & 2.67 \\
\hline Fruit & 116 & 117 & 2.48 \\
\hline Vegetables & 117 & 116 & 2.46 \\
\hline Sugar, jam, honey, chocolate and confectionery & 118 & 127 & 2.69 \\
\hline Food products n.e.c. & 119 & 127 & 2.69 \\
\hline Coffee, tea and cocoa & 121 & 127 & 2.69 \\
\hline Mineral waters, soft drinks, fruit and vegetable juices & 122 & 127 & 2.69 \\
\hline Spirits & 211 & 52 & 1.1 \\
\hline Tobacco & 220 & 93 & 1.97 \\
\hline Garments & 312 & 127 & 2.69 \\
\hline Other articles of clothing and clothing accessories & 313 & 126 & 2.67 \\
\hline Footwear including repair & 321 & 122 & 2.58 \\
\hline Materials for the maintenance and repair of the dwelling & 431 & 110 & 2.33 \\
\hline Furniture and furnishings & 511 & 127 & 2.69 \\
\hline Carpets and other floor coverings & 512 & 110 & 2.33 \\
\hline Household textiles & 520 & 127 & 2.69 \\
\hline Major household appliances whether electric or not and small electric household appliances & 531 & 110 & 2.33 \\
\hline Major household appliances whether electric or not and small electric household appliances & 532 & 121 & 2.56 \\
\hline Glassware, tableware and household utensils & 540 & 126 & 2.67 \\
\hline Tools and equipment for house and garden & 551 & 23 & 0.49 \\
\hline Tools and equipment for house and garden & 552 & 125 & 2.65 \\
\hline Non-durable household goods & 561 & 127 & 2.69 \\
\hline Pharmaceutical products & 611 & 36 & 0.76 \\
\hline Other medical products; therapeutic appliances and equipment & 612 & 52 & 1.1 \\
\hline Other medical products; therapeutic appliances and equipment & 613 & 41 & 0.87 \\
\hline Motor cars & 711 & 51 & 1.08 \\
\hline Motor cycles, bicycles and animal drawn vehicles & 712 & 7 & 0.15 \\
\hline Motor cycles, bicycles and animal drawn vehicles & 713 & 57 & 1.21 \\
\hline Spares parts and accessories for personal transport equipment & 721 & 125 & 2.65 \\
\hline Equipment for the reception, recording and reproduction of sound and pictures & 911 & 83 & 1.76 \\
\hline Photographic and cinematographic equipment and optical instruments & 912 & 81 & 1.71 \\
\hline Information processing equipment & 913 & 31 & 0.66 \\
\hline Recording media & 914 & 89 & 1.88 \\
\hline Major durables for indoor and outdoor recreation including musical instruments & 921 & 95 & 2.01 \\
\hline Major durables for indoor and outdoor recreation including musical instruments & 922 & 73 & 1.55 \\
\hline Games, toys and hobbies & 931 & 105 & 2.22 \\
\hline Equipment for sport, camping and open-air recreation & 932 & 127 & 2.69 \\
\hline Gardens, plants and flowers & 933 & 110 & 2.33 \\
\hline Pets and related products; veterinary and other services for pets & 934 & 116 & 2.46 \\
\hline Miscellaneous printed matter; stationery and drawing materials & 953 & 25 & 0.53 \\
\hline Miscellaneous printed matter; stationery and drawing materials & 954 & 123 & 2.6 \\
\hline Electrical appliances for personal care; other appliances, articles and products for personal care & 1212 & 57 & 1.21 \\
\hline Electrical appliances for personal care; other appliances, articles and products for personal care & 1213 & 123 & 2.6 \\
\hline Other personal effects & 1232 & 127 & 2.69 \\
\hline
\end{tabular}

